\title{
Quellen und Literatur
}

\author{
Unveröffentlichte Quellen
}

\section{Archive}

\section{Israel}

Archiv der Arbeiterbewegung im Lavon-Institut, Tel Aviv (LI)

Akte III - $38-43$ - 12, Deutschland-Tagebuch.

Sitzungsprotokolle des Exekutivrates der Histadrut (Gewerkschaft) 1933-1938.

\section{Beit Lochamei-Ha-Ghettaot (Ghetto-Fighter-House) (GFH)}

Archiv des Hechalutz in Polen Z8/1.

Central Archives for the History of the Jewish People (Zentralarchiv für die Geschichte des jiidischen Volkes), Jerusalem (CAHJP)

Inv. $78 \quad-$ Zentralwohlfahrtsstelle.

Inv. 165 (1) - Zusammenkunft jüdischer Sozialarbeiter, Frankfurt a. M. 1932.

Inv. 124 (21) - Canadian Jewish Congress, campaign for Relief Stricken European Jewry.

Inv. 1419 - Council for German Jewry. Statistics of Jewish Emigration from Greater Germany, 1933-1939.

Inv. 4631 - Die Juden und jüdische Mischlinge in Großdeutschland, 17.5. 1939, Maschinenschrift.

N1/48 Ansbach.

B-33 Bingen.

Inv. 6528 - Gemeinde Darmstadt.

Sammlung Wolf.

Central Zionist Archives (Zionistisches Zentralarchiv), Jerusalem (CZA)

A 127 - Nachlaß Yitzchak Grünbaum.

A 140 - Nachlaß Salomon Adler-Rudel.

A 142 - Nachlaß Alfred Klee.

L 13 - Zentralstelle für die Ansiedlung deutscher Juden in Palästina, London.

L 22 - Vertretung der Zionistischen Welt Organisation und der Jewish Agency beim Völkerbund, Genf.

S 6 - Einwanderungsabteilung.

S 7 - Zentralstelle für die Ansiedlung deutscher Juden in Palästina.

Sitzungsprotokolle der Exekutive der Jewish Agency in Palästina 1933-1938.

Sitzungen des „engeren zionistischen Exekutivkomitees“.

Bericht der Zionistischen Vereinigung für Deutschland an den XXV. Delegiertentag in Berlin, 2.-4. Februar 1936, Berlin 1936.

Zehn Jahre „Verband Russischer Juden in Deutschland“. Ein Rückblick (gegründet 1920).

Centre for Oral Documentation at the Institute for Contemporary Jewry, The Hebrew University of Jerusalem (IfCJ)

Bodenheimer, Wolf 11 (32).

Bromberger, Esriel $26(30)$.

Gross, Yitzchak 10 (32).

Gschuri, Meir 2 (30).

Walk, Joseph 25 (30). 
Meir, Franz 4 (41).

Nachmani, Ady 2 (70).

Leo Baeck Institute Jerusalem (LBIJ)

Protokoll der Sitzung des Zentralausschusses der deutschen Juden für Hilfe und Aufbau - LBIJ $553 / 2$.

Rav-Kook-Institute, Jerusalem (RKI)

Bachad, Informationsrundschreiben November 1935.

HaNe'eman, Orthodoxes Monatsblatt für die junge Generation, Monate Tishre-Cheschwan 5688 (1928).

Unser Gedank - Organisation der Misrachi-Jugend (Lemberg), Lvov 1933.

Rekonstruiertes Archiv der "Reichvertretung der deutschen Juden", The Hebrew University of Jerusalem $(R V)$

Yad-Vashem-Archiv, Jerusalem (YVA)

Sammlungen:

01 - Ball-Kaduri.

02 - Wiener.

03 - Zeugnisaussagen.

08 - Deutschland.

$M-1 /$ E Zeugnisaussagen.

JM/2866 - Mikrofilme des deutschen Auswärtigen Amtes.

\section{Deutschland}

\section{Bundesarchiv Koblenz (BAK)}

R 43II Reichskanzlei.

R 57 Deutsches Ausland-Institut.

Bundesarchiv Abteilungen Potsdam (BAP)

Dienststellen Rosenberg.

09.03 Konsulat Temesvar.

15.01 Reichsministerium des Innern.

Reichsministerium für Volksaufklärung und Propaganda Nr. 1158.

Brandenburgisches Landeshauptarchiv (BLHA)

Pr. Br. Rep. 6 B Kreisverwaltung Beerkow-Shorkow 834.

Landesarchiv Berlin (LaB)

Amtsgericht Charlottenburg, Rep. 42 Acc 1743 Nr. 9006.

Politisches Archiv des Auswärtigen Amtes (PAAA)

Aktenbestand Inland II A, B.

Staatsarcbiv Hamburg (StA Hamburg)

Auswanderungsamt I.

Deutsch-Israelitische Gemeinde in Hamburg:

Sitzungsprotokolle des Gemeindevorstandes.

Sitzungsprotokolle des Repräsentantenkollegiums.

Amtsgericht Hamburg - Vereinsregister.

6221 - Familie Plaut.

Oberfinanzpräsident 314-315.

Handschriftensammlung.

Sächsisches Hauptstaatsarchiv Dresden (StA Dresden)

Zeitungsausschnittsammlung Nr. 583.

Ministerium des Innern Nr. 11180. 
Staatsarchiv Leipzig (StA Leipzig)

Devisen-Stelle-Leipzig 185.

PP-V 4406 Bestand Polizeipräsidium.

Staatsarchiv Abteilung Merseburg (GStA Merseburg)

Rep. 169 D II CF.

\section{USA (New York)}

Jewish Joint Distribution Committee (JDC)

78 - Campaigns 1937-1939.

172 - JDC Overseas Administration, General 1933-1940.

225 - Federation of Polish Jews in America, 1933-1935.

226 - Federation of Polish Jews in America, 1936.

228 - Federation of Polish Jews in America, 1938.

626 - Germany, General 1933 (März - Juli).

628 - Germany, General 1934.

629 - Germany, General 1935.

645 - Germany, Zentral Ausschuß der deutschen Juden für Hilfe und Aufbau 1933-1934 (Juni).

646 - Germany, Zentral Ausschuß der deutschen Juden für Hilfe und Aufbau 1934-1938 (Juli).

788 - Poland, General 1933-1935 (Mai).

790 - Poland, General 1936.

193 - Poland, General 1938.

874 - Poland, Refugees General 1934; 1937-1939.

878 - Poland, Refugees Zbanszyn, 1938-1939.

Leo Baeck Institute Archiv (LBI-N.Y.)

Komitee für den Osten (K.f.d.O.).

William Graetz Collection AR 4121.

Max Kreutzberger Collection AR 7183.

Robert Weltsch Collection AR 7185.

YIVO Institute for Jewish Research Archive (YIVO)

RG 31 Territorial Collection Germany (from Vilna Archives).

RG 116 Territorial Collection Germany (from NY Archives).

RG 347 American Jewish Committee, Collection Waldmann.

RG 348 Papers of Lucien Wolf and David Mowshowitch.

\section{Polen (Warschau)}

Archiwum Akt Nowych (AAN)

Amb Rp w Berlinie.

Żydowski Instytut Historyczny (ZIH)

Synagogen Gemeinde zu Breslau.

Zjednoczony Komitet Żydowski Niesienia Uchodzcom z Niemiec we Lwowie.

\section{Rußland (Moskau)}

\section{Sonderarchiv (SoA)}

1230 Weltverband der Jüdischen Studentenschaft.

RSHA, 500/1: Reichssicherheitshauptamt.

1325/1: Dokumentensammlung über die Lage der Juden in verschiedenen Ländern.

721: Bestand „Central Verein deutscher Staatsbürger jüdischen Glaubens“. 


\section{Bibliotheken}

Wiener Library (Tel Aviv)

613 - Jewish Central Information Office.

Aid to Jews Overseas. Report on the Activities of the American Jewish Joint Distribution Committee for the Year 1935, including a brief Résumé for the Year 1936.

Dunker, Abraham B., The Situation of the Jews in Poland, New York, American Jewish Congress 1936.

Liberman, Kopel, Le Boycottage Économique de L’Allemagne, Brüssel 1934.

Peoples Ort Federation Bulletin, 1934.

Protocole de la II Conférence Juif Mondiale, Genève, 5-8 Septembre 1933.

Protocole de la III Conférence Juif Mondiale, Genève, 20-23 Août 1934.

Protocole du premier Congres Juif Mondial, Genève, 8-15 Août 1936.

Rontch, I. E., "The Present State of the Landsmannschaften", in: The Jewish Social Service Quarterly 15.4 (Juni 1939).

Schorr, Moshe, The Present Position of the Jews in Poland, London 1935.

Speeches delivered at the Anglo-Jewish Conference convened by the Council for German Jewry at the Dorchester Hotel on Sunday, 15. 3. 1936, London 1936.

Tartakower, Arieh/Grossmann, Kurt R., The Jewish Refugee, Institute of Jewish Affairs of the American Jewish Congress and World Jewish Congress, New York 1944.

The „ORT"-Union in 1934/1935. Report of the Executive of the Central Board for the Period from January 1st 1934 to August 31 st 1935 submitted to the plenary Session of the C. B. held in Paris on November 16-20 1935.

Deutsche Bibliothek - Deutsche Bücherei Leipzig (DBL)

Frecks, Rudolf, Das rassische Erwachen des deutschen Volkes. Nationalsozialistische Aufklärungsschriften, Heft 5, Berlin 1936.

Die Juden in Deutschland. Herausgegeben vom Institut zum Studium der Judenfrage, München 1936.

Hartenstein, Johannes G., Die Juden in der Geschichte Leipzigs. Von der Entstehung der Stadt an bis zur Mitte des 19. Jahrhunderts, Berlin 1938.

Rose, Franz, Juden richten sich selbst, Berlin 1938.

Seifert, Hermann Erich, Der Jude an der Ostgrenze. Der Osten Europas, Bd. 3, Berlin 1942.

Seraphim, Peter-Heinz, Die Wanderungsbewegung des jüdischen Volkes. Schriften zur Geopolitik, Heft 18, Heidelberg/Berlin/Magdeburg 1940.

\section{Veröffentlichte Quellen}

Akten zur Deutschen Auswärtigen Politik, Göttingen, Serie C: 1933-1937 Das Dritte Reich: Die Ersten Jahre, Band III, Band IV.

Artl, Fritz, Volksbiologische Untersuchungen über die Juden in Leipzig, 4. Beiheft zum Archiv für Bevölkerungswissenschaft und Bevölkerungspolitik Band VII, Leipzig 1938.

Aus Geschichte und Leben der Juden in Leipzig. Festschrift zum 75jährigen Bestehen der Leipziger Gemeindesynagoge. Herausgegeben vom Vorstand der Israelitischen Religionsgemeinde 1930.

Boehlich, Walter (Hrsg.), Der Berliner Antisemitismusstreit, Frankfurt a. M. 1988.

Deutschland-Berichte der Sozialdemokratischen Partei Deutschlands (SoPaDe), Prag 1934-1940.

Einstein, Albert, About Zionism, London 1930.

Feinberg, Natan, Ha-ma'arechet ha-yehudit neged Hitler al bimat chever ha-leumim (Hapetitia shel Bernheim), Jerusalem 1957 [Die jüdische Kampagnc gegen Hitler beim Völkerbund (Die Bernheim-Petition)].

Grünbaum, Yitzchak, Evacuatia ve-yetzia, in: ders., Milchemot yehudei polania, Tel Aviv 1971, S. 407-425 [Evacuation and Departure, in: ders. (Hrsg.), The Wars of Polish Jewry 1913-1940]. 
Jüdische Gesellschaften und Institutionen in Paris im Jahre 1939, bearbeitet von A. A., in: A. Tscherikower, Juden in Frankreich. Studien und Materialien (jidd.).

Kollenscher, Max, Jüdisches aus der deutsch-polnischen Übergangszeit Posen 1918-1920, Berlin 1925.

Lestschinsky, Jacob/Erev Churban, Vom jüdischen Leben in Polen 1935-1937 (jidd. - En Vispera de La Destruccion), Buenos Aires 1951.

Mahler, R., The Ringelblum Letters (hebr.), in: Yalkut Moreshet, 2.2 (Mai 1964), S. 17-31.

Meldungen aus dem Reich 1938-1945. Die geheimen Lageberichte des Sicherheitsdienstes der SS. Herausgegeben und eingeleitet von Heinz Boberach, Herrsching 1984.

Renner, Karl, Die Nation: Mythos und Wirklichkeit, Wien 1964.

Sneh, Moshe, Writings Vol. 1, 1928-1939 (herausgegeben von Emanuel Melzer), Tel Aviv 1995.

Sokolow, Nahum, Referat über die gegenwärtige Lage der Juden in der Welt, in: Stenographisches Protokoll der Verhandlungen des XVIII. Zionistenkongresses und der Dritten Tagung des Council der Jewish Agency für Palästina, Wien 1933, S. 170-185.

Stenographisches Protokoll der Verhandlungen des XVIII. Zionistenkongresses und der Dritten Tagung des Council der Jewish Agency für Palästina, Wien 1933.

Stenographisches Protokoll der Verhandlungen des XIX. Zionistenkongresses und der Vierten Tagung des Council der Jewish Agency für Palästina, Luzern 20.8.-6.9.1935, Jerusalem.

Unna, Isak, Sefer shoalin ve-dorschin kolel she'elot u-tschuvot ve-chen drashot me-isvono shel har-rav Dr. Isak Unna), Tel Aviv 1974 [Fragen und Auslegungen, einschließlich der Responsen und Predigten aus dem Nachlaß des ehrwürdigen Rabbiners Dr. Isak Unna].

Walk, Joseph (Hrsg.), Das Sonderrecht für die Juden im NS-Staat. Eine Sammlung der gesetzlichen Maßnahmen und Richtlinien - Inhalt und Bedeutung, Heidelberg 1981.

Weinberg, Yechiel J., Sridei esh, she'elot u-tschuvot chidushim u-vi'urim, Jerusalem [Überlebende des Feuers. Neue, klärende Responsen].

\section{Zeitungen - Zeitschriften}

Centralvereins Zeitung: Blätter für Deutschtum und Judentum, Berlin 1922-1938.

Der Israelit: Ein Centralorgan für das orthodoxe Judentum, Frankfurt a. M. 1918-1938.

Der Jude: Eine Monatsschrift, Berlin 1916-1923.

Der Morgen: Monatsschrift der deutschen Juden, Darmstadt 1933-1935.

Der Nationaldeutsche Jude, 1933-1934.

Der Neue Morgen, 1933 (jidd.).

Der Orient, $1848-1849$.

Der Schild: Zeitschrift des Reichsbundes jüdischer Frontsoldaten, Berlin 1933-1935.

Die Welt: Zentralorgan der zionistischen Bewegung, Berlin 1910.

He-Atid, Zeitung der „Hechalutz“-Weltorganisation, Warschau 1933-1934 (hebr.).

Haynt, Warschau, 1933-1938 (jidd.).

Im deutschen Reich: Zeitschrift des Centralvereins deutscher Staatsbürger jüdischen Glaubens, Berlin 1916-1922.

Informationsblätter des Zentralausschusses für Hilfe und Aufbau, 1933.

Israelitisches Familienblatt, Hamburg 1918-1938.

Jüdisches Gemeindeblatt Danzig, 1932-1938.

Jüdische Rundschau, Berlin 1918-1938.

Jüdische Telegraphen Agentur.

Jüdische Wohlfahrtspflege und Sozialpolitik. Zeitschrift der Zentralwohlfahrtsstelle der deutschen Juden und der Abteilung Wirtschaftshilfe bei der Reichsvertretung der Juden in Deutschland, Berlin 1933-1938.

Jüdische Zeitung, 1933-1938.

Netiva, "Ze'irei Misrachi“ (Mischrachi-Jugend) - Deutschland, Heft 10, 1930 (hebr.).

Neue jüdische Monatshefte: Zeitschrift für Politik, Wirtschaft und Literatur in Ost und West, Berlin 1916-1920.

Ost und West: Illustrierte Monatsschrift für das gesamte Judentum, Berlin 1918-1923.

YIVO-Blätter, September 1934 (jidd.).

ZVfD Blätter, 1934. 


\section{Tagebücher, Briefe, Memoiren}

Ben-Gurion, David, Sichronot min ha-isavon, 5. Bd., 1938, Tel Aviv 1982 [Erinnerungen aus dem Nachlaß].

Blumenfeld Kurt, Erlebte Judenfrage. Ein Vierteljahrhundert deutscher Zionismus, Stuttgart, 1962.

Even-Shoshan, Shlomo (Hrsg.), Sipuro shel kibbutz-hakshara ..., Tel Aviv 1970 [The Story of Kibbutz-Hakshara - Kibbutz Borocov at Lodz and its Surroundings].

Katz, Jacob, With my Own Eyes. The Autobiography of an Historian, Hanover 1995.

Lipski, Jozef, Diplomat in Berlin, 1933-1939, Papers and Memoirs of Jozef Lipski, Ambassador of Poland, New York 1968.

Nishmit, Sara, Haju Chalutzim be-Lita, 1916-1941, Beit Lochamei ha-Ghettaot 1982 [Pioniere in Litauen, 1916-1941].

Rosenfeld, Else/Luckner, Gertrud, Lebenszeichen aus Piaski, Briefe Deportierter aus dem Distrikt Lublin 1940-1943, München 1968.

\section{Literatur}

Adam, Uwe, Judenpolitik im Dritten Reich, Tübingen 1972.

Adelson, Jozef, Minian uchlusiat ha-yehudim esrechei polin be-Germania ba-shanim 1919-1939, in: Gal-Ed 11 (1989), S. 97-108 [The Number of Jewish Polish Citizens in Germany, 1919-1939].

Adler, H. G., Der verwaltete Mensch. Studien zur Deportation der Juden aus Deutschland, Tübingen 1974.

Adler-Rudel, Shalom, Ostjuden in Deutschland, 1880-1940. Zugleich eine Geschichte der Organisationen, die sie betreuten, Tübingen 1959.

Ders., The Evian Conference on the Refugee Question, in: Leo Baeck Institute Yearbook 13 (1968), S. 235-273.

Ders., Jüdische Selbsthilfe unter dem Naziregime 1933-1939. Im Spiegel der Berichte der Reichsvertretung der Juden in Deutschland, Tübingen 1974.

Aly, Götz/Heim, Susanne, Vordenker der Vernichtung. Auschwitz und die deutschen Pläne für eine neue europäische Ordnung, Frankfurt a. M. 1993.

Anderle, Gabriele, Die ,Zentralstellen für jüdische Auswanderung in Wien, Berlin und Prag ein Vergleich, in: Tel Aviver Jahrbuch für deutsche Geschichte 23 (1994), S. 275-299.

Arendt, Hannah, The Origins of Totalitarianism, Cleveland 1969.

Aschheim, Steven, Brothers and Strangers. The East European Jew in Germany and German Jewish Consciousness, 1800-1923, Madison 1982.

Ders., Caftan and Cravat. The Ostjude as a Symbol in the Development of German Anti-Semitism, in: Seymour Drescher/David Sabean/Allan Sharlin (Hrsg.), Political Symbolism in Modern Europe. Essays in Honour of George L. Mosse, New Brunswick 1982, S. 81-99.

Ders., Eastern Jew, German Jew and Germany's Ostpolitik in the First World War, in: Leo Baeck Institute Yearbook 28 (1983), S. 351-365.

Ders., The East European Jew and German Jewish Identity, in: Studies in Contemporary Jewry 1 (1984), S. 3-25.

Avizohar, Meir, Bi-rei saduk. Idealim chevratiim u-leumiim ve-hishtakfutam ba-olam shel Mapai, Tel Aviv, 1990, S. 128f. [In a Cracked Mirror: Social and National Ideals and Their Reflection in the World of Mapai].

Bacon, Gershon C., Agudat Israel in Interwar Poland, in: Yisrael Gutman/Ezra Mendelsohn u. a. (Hrsg.), The Jews in Poland between the two World Wars, Hanover 1986, S. 20-35.

Balaban, Meir, Ha-yedudim be-Polin ba-mea ha-16 u-va-machazit ha-rishona shel hamea ha-17 [Jews in Poland in the Sixteenth Century and the First Half of the Seventeenth Century], in: Y. Heilprin (Hrsg.), Beit Yisrael be-Polin mi-yamim rishonim ve-ad le-ymot ha-churban, Bd. 1, Jerusalem 1948, S. 5-44 [Polish Jewry from its Origins to its Destruction].

Bankier, David, Ha-chevra ha-germanit ve-ha-antishemiut ha-national sozialistit 1933-1938. Perek be-yachasei mishtar-uchlusia ba-Reich ha-shlishi be-rei dochot sodiim al „daat kahal“, 
Diss., Jerusalem 1983, S. 22-163 [German Society and National Socialist Antisemitism, 1933-1938].

Ders., Die öffentliche Meinung im Hitler-Staat. Die „Endlösung“ und die Deutschen. Eine Berichtigung, Berlin 1995.

Barkai, Avraham, Vom Boykott zur „Entjudung“. Der wirtschaftliche Existenzkampf der Juden im Dritten Reich 1933-1943, Frankfurt a. M. 1987.

Ders., German Interests in the Haavara-Transfer Agreement 1933-1939, in: Leo Baeck Institute Yearbook 35 (1990), S. 245-266.

Baron, Salo Wittmayer, The Russian Jew under Tsars and Soviets, New York 1964.

Bartal, Israel, ,The Heavenly City of Germany' and Absolutism à la Mode d'Autriche: The Rise of the Haskalah in Galicia, in: Jakob Katz (Hrsg.), Towards Modernity. The European Jewish Model, New Brunswick 1987, S. 33-42.

Bauer, Yehuda, My Brother's Keeper. A History of the American Jewish Joint Distribution Committee, 1929-1939, Philadelphia 1974.

Ders., The Holocaust in historical Perspective, Seattle 1978.

Ders., The Jewish Emergence from Powerlessness, London 1980.

Ders., T'guvot beet ha-shoa. Nisionot amida, hitnagdut, hazala, Tel-Aviv 1983 [Jewish Reactions to the Holocaust. Rescue Attempts, Unarmed and Armed Resistance].

Ders., Jews for Sale? Nazi-Jewish Negotiations, 1933-1945, New Haven 1994.

Bayertz, Kurt, Solidarität: Begriff und Problem, Frankfurt a.M.1998.

Ders., Begriff und Problem der Solidarität, in: ders., Solidarität: Begriff und Problem der Solidarität, Frankfurt a. M. 1998, S. 11-53.

Beit-Zwi, S. B., Ha-Zionut ha-post-ugandit be-mashber ha-shoa. Mechkar al gormei mishgeha shel ha-tnua ha-zionit be-shanim 1938-1945, Tel-Aviv 1977 [Post-Ugandian Zionism in the Crucible of the Holocaust 1938-1945].

Benari, J., Tochnit ha-evakuazia shel S. Jabotinsky ve-chasoto et goral-yehudei Polin, o.O. Dezember 1969 [S. Jabotinskys Evakuierungs-Programm und seine Sicht des Schicksals des polnischen Judentums].

Ben-Avner, Yehuda, Devarim le-teur peilutam shel rabbanim ne'emanei ha-thora be-germania (mi-michtavei benei doram ha-acharon, 1920-1938), in: Sinai 46 (1982),140-155 [Anmerkungen zur Arbeit gesetzestreuer Rabbiner in Deutschland (Briefe der letzten Generation, 1920-1938)].

Ders., Vom orthodoxen Judentum in Deutschland zwischen zwei Weltkriegen, Hildesheim 1987.

Ben-Elissar, Eliahu, La Diplomatie du IIIe Reich et les Juifs (1933-1939), Paris 1969.

Berding, Helmut, Moderner Antisemitismus in Deutschland, Frankfurt 1988.

Bering, Dietz, Kampf um Namen. Bernhard Weiß gegen Joseph Goebbels, Stuttgart 1991.

Bernstein, Aharon, Ha-Kabtsanim. Perek be-Toledot Yehudei Germania, Jerusalem 1992, 53-57 [Die Bettler. Ein Kapitel aus der Geschichte der deutschen Juden].

Biale, David, Power and Powerlessness in Jewish History, New York 1986.

Birnbaum, Pierre/Katznelson, Ira (Hrsg.), Paths of Emancipation. Jews, States and Citizenship, Princeton 1997.

Dies., Emancipation and the Liberal Offer, in: dies. (Hrsg.), Paths of Emancipation. Jews, States and Citizenship, Princeton 1997, S. 3-36.

Black, Edwin, The Transfer Agreement. The Untold Story of the Secret Agreement between the Third Reich and Jewish Palestine, New York 1984.

Blatman, Daniel, Ha-bund be-polin ba-shanim 1935-1939 [The Bund in Poland, 1935-1939], in: Yahadut semanenu (Contemporary Judaism) 8 (1993), S. 69-97.

Brechtken, Magnus, „Madagaskar für die Juden“. Antisemitische Idee und politische Praxis 1885-1945, München 1997.

Brenner, Michael, The Jüdische Volkspartei - National Jewish Communal Politics during the Weimar Republic, in: Leo Baeck Institute Yearbook 35 (1990), S. 219-243.

Ders., The Renaissance of Jewish Culture in Weimar Germany, New Haven 1996.

Breuer, Mordechai, Jüdische Orthodoxie im deutschen Reich 1871-1918. Sozialgeschichte einer religiösen Minderheit, Frankfurt a. M. 1986.

Brubaker, Roger, Staats-Bürger. Frankreich und Deutschland im historischen Vergleich, Hamburg 1994. 
Brumberg, Abraham, The Bund and the Polish Socialist Party in the late 1930s, in: Yisrael Gutman/Ezra Mendelsohn u.a. (Hrsg.), The Jews in Poland between the two World Wars, Hanover 1986, S. 75-94.

Cohen, Raya/Ringelblum, Emmanuel: Between Historiographical Tradition and unprecedented History, in: Gal-Ed 15-16 (1997), S. 105-117.

Diner, Dan, Die Katastrophe vor der Katastrophe: Auswanderung ohne Einwanderung, in: Dirk Blasius/Dan Diner (Hrsg.), Zerbrochene Geschichte. Leben und Selbstverständnis der Juden in Deutschland, Frankfurt a. M. 1991, S. 138-160.

Ders., ,Meines Bruders Wächter'. Zur Diplomatie jüdischer Fragen 1840-1919, in: Barbara Picht (Hrsg.), Ich handle mit Vernunft. Ein Almanach zum fünfzehnjährigen Bestehen der Literaturbuchhandlung, München 1997, S. 24-37.

Ders., Das Jahrhundert verstehen: Eine universalhistorische Deutung, München 1999.

Dunker, Ulrich, Der Reichsbund jüdischer Frontsoldaten 1919-1938. Geschichte eines jüdischen Abwehrvereins, Düsseldorf 1977.

Elam, Yigal, Mavo le-historia zionit acheret, Tel Aviv 1975 [An Introduction to Zionist Counter History ].

Eldar, Menachem, Ha-Mifgash ben Yehudei Germania vi-Yhudei Polin be-Milchemet HaOlam ha-rischona, M.A., Universität Bar-Ilan, Ramat Gan 1981 [Die Begegnung zwischen deutschen und polnischen Juden im Ersten Weltkrieg].

Endelman, Todd, Comparing Jewish Societies, Ann Arbor, 1997.

Eppler, Elisabeth A., Peulot hatsala ve-esra be-shanim 1933-1945 mitaam ha-congress hayehudi ha-olami, in: Gesher 16.2-3 (1970), S. 173-207 [The Rescue Work of the World Jewish Congress in World War II].

Etkes, Emanuel, Immanent factors and external influences in the development of the Haskalah movement in Russia, in: Jacob Katz (Hrsg.), Towards Modernity. The European Jewish Model, New Brunswick 1987, S. 13-32.

Fahrmeier, A., Nineteenth-Century German Citizenship: A reconsideration, in: The Historical Journal 40.3 (September 1997), S. 721-725.

Feilchenfeld, Werner/Michaelis, Dolf/Pinner, Ludwig, Haavara-Transfer nach Palästina und Einwanderung deutscher Juden 1933-1939, Tübingen 1972.

Fox, John B., Reichskristallnacht 9 November 1938 and the Ostjuden Perspektive. To the Nazi Search for a ,Solution' to the Jewish Question, in: Polin 5 (1990), S. 74-102.

Fraenkel, Daniel, Al pi Tehom. Ha-mediniut ha-zionit u-sheelat yehudei germania 1933-1938, Jerusalem 1994 [On the Edge of Abyss. Zionist Policy and the Plight of the German Jews 1933-1938].

Frankel, Jonathan, Assimilation and the Jews in 19th Century Europe: Toward a New Historiography?, in: ders./Steven Zipperstein (Hrsg.), Assimilation and Community: The Jews in Nineteenth-Century, Cambridge 1992, S. 1-37.

Freeden, Herbert, Jüdische Presse im Dritten Reich, Frankfurt a.Main 1987.

Freud, Sigmund, Das Unbehagen an der Kultur, Wien 1930.

Friedländer, Saul, Nazi-Germany and the Jews. The Years of Persecution, 1933-1939, New York 1997.

Friesel, Evyatar, The Political and Ideological Development of the Centralverein before 1914, in: Leo Baeck Institute Yearbook 31 (1986), S. 121-146.

Gelber, Yoav, Ha-mediniut ha-zionit ve-heskem ha-haavara, in: Yalkut Moreshet 17 (1974), S. 97-152; Yalkut Moreshet 18 (1974), S. 23-100 [Zionist Policy and the Transfer Agreement 1933-1935].

Gierowski, A., Die Juden in Polen im 17. und 18. Jahrhundert und ihre Beziehungen zu den deutschen Städten von Leipzig bis Frankfurt a. M., in: Karl Erich Grözinger (Hrsg.), Die wirtschaftlichen und kulturellen Beziehungen zwischen den jüdischen Gemeinden in Polen und Deutschland vom 16. bis zum 20. Jahrhundert, Wiesbaden 1992, S. 3-19.

Gilman, Sander I., The Rediscovery of Eastern Jews: German Jews in the East, 1890-1918, in: David Bronsen (Hrsg.), Jews and Germans from 1860 to 1933: The Problematic Symbiosis, Heidelberg 1979, S. 338-365.

Ders., Rasse, Sexualität und Seuche. Stereotype aus der Innenwelt der westlichen Kultur, Hamburg 1992. 
Ders., Das jüdische Witzbuch. Sigmund Freud und die verborgene Sprache der Juden, in: ders., Rasse, Sexualität und Seuche. Stereotype aus der Innenwelt der westlichen Kultur, Hamburg 1992.

Ders., Der jüdische Körper. Eine Fußnote, in: ders., Rasse, Sexualität und Seuche. Stereotype aus der Innenwelt der westlichen Kultur, Hamburg 1992.

Gitman, Joseph, The Jews and Jewish Problems in the Parliament, 1919-1939, Diss., Yale University 1963.

Golczewski, Frank, Polnisch-jüdische Beziehungen 1881-1922, Wiesbaden 1981.

Goldberg, Bettina, Die Zwangsausweisung der polnischen Juden aus dem deutschen Reich im Oktober 1938 und die Folgen, in: Zeitschrift für Geschichtswissenschaft 46 (1998), S. 971-984.

Goldstein, Jacob/Shavit, Yaakov, Le-lo psharot. „Heskem Ben-Gurion-Jabotinsky“ vechishlono 1934-35, Tel Aviv 1979, S. 14 ff. [Without Compromise: The „Ben-Gurion-Jabotinsky Agreement" and its Failure 1934-1935].

Gosewinkel, Dieter, Citizenship and Nationhood: The Historical Development of the German Case, in: U. K. Preiss/F. Requejo (Hrsg.), European Citizenship, Multiculturalism, and the State, Baden-Baden 1998, S. 125-135.

Gottlieb, M., The Anti-Nazi Boycott Movement in the American Jewish Community, 1933-1941, Diss., Brandeis University 1967.

Gotzmann, Andreas, Rabbiner und Bann. Zur Problematik der Analyse und Bewertung zweier Topoi des aufklärerischen Denkens, in: Aschkenas 4 (1994), S. 99-125.

Grünberg, Karol, The Atrocities against the Jews in the Third Reich as seen by the NationalDemocratic Press (1933-1939), in: Polin 5 (1990), S. 103-113.

Gutman, Yisracl, Polish Antisemitism between the Wars: An Overview, in: ders./Ezra Mendelsohn/Jehuda Reinharz/Chone Shmeruk (Hrsg.), The Jews of Poland between two World Wars, Hanover 1986, S. 97-108.

Gutwein D., Jewish Diplomacy in the Nineteenth Century: The Beginning of Jewish Nationalism?, in: J. Reinharz/G. Shimoni/Y. Salmon (Hrsg.), Jewish Nationalism and Politics: New Perspectives (hebr.), Jerusalem 1996, S. 159-176.

Hagen W. W., Before the ,Final Solution': Toward a Comparative Analysis of Political AntiSemitism in Interwar Germany and Poland, in: The Journal of Modern History 68.1 (1996), S. 351-381.

Halamish, Aviva, Mediniut ha-aliah ve-ha-klita shel ha-histadrut ha-zionit, Diss., Tel Aviv 1995 [Immigration and Absorption Policy of the Zionist Organization].

Halevi, H. S., The Influence of World War II on the Demographic Characteristic of the Jewish People (hebr.), Diss., Jerusalem 1960.

Halevi, Nadav, Ha-hitpatchut ha-kalkalit shel ha-yishuv ha-yehudi be-Erez-Israel 1917-1947, Jerusalem 1979 [Economic Development of the Yishuv in Palestine 1917-1947].

Hartglas, A., Milchemot Yehudei Polin al sechuyotekem ha-esrachiot ve-ha-leumiot [Der Kampf polnischer Juden um ihre nationalen und bürgerlichen Rechte], in: Y. Heilprin (Hrsg.), Beit Yisrael be-Polin mi-yamim rishonim ve-ad le-ymot ha-churban, Bd. 1, Jerusalem 1948, S. 128-151 [Polish Jewry from its Origins to its Destruction].

Haumann, Heiko, Geschichte der Ostjuden, München 1990.

Heid, Ludger, Maloche - nicht Mildtätigkeit. Ostjüdische Arbeiter in Deutschland 1914-1923, Hildesheim 1995.

Heim, Susanne, ,Deutschland muß ihnen ein Land ohne Zukunft sein'. Die Zwangsemigration der Juden 1933 bis 1938, in: Beiträge zur nationalsozialistischen Gesundheits- und Sozialpolitik 11 (1993), S. 48-81.

Heuberger, Rachel, Die jüdischen Parteien im polnischen Parlament nach dem Ersten Weltkrieg, in: Michael Brocke (Hrsg.), Beter und Rebellen. Aus 1000 Jahren Judentum in Polen, Frankfurt a. M. 1983, S. 237-259.

Hilberg, Raul, Die Vernichtung der europäischen Juden, Frankfurt a. M. 1990.

Hildesheimer, Esriel, Jüdische Selbstverwaltung unter dem NS-Regime. Der Existenzkampf der Reichsvertretung und Reichsvereinigung der Juden in Deutschland, Tübingen 1994.

Hobsbawm, Eric J., Nationen und Nationalismus. Mythos und Realität seit 1780, München 1996. 
Horowitz, Dan/Lissak, Moshe, Mi-Yishuv li-medina: Yehudei Erez-Israel bi-tkufat ha-mandat ha-briti ke-kehila-politit, Tel Aviv 1977, S. 67f. [From Yishuv to State: The Jews of Palestine in the British Mandate Period as a Political Community].

Israel, Jonathan, European Jewry in the Age of Mercantilism 1550-1750, Oxford 1985.

Jacobmeyer, Wolfgang, Vom Zwangsarbeiter zum heimatlosen Ausländer. Die Displaced Persons in Westdeutschland 1945-1951, Göttingen 1985.

Jacobs, Jack, Ein Freund in Not. Das jüdische Arbeiterkomitee in New York und die Flüchtlinge aus den deutschsprachigen Ländern, 1933-1945, Bonn 1993.

Janowsky, Oscar I., The Jews and Minority Rights (1898-1919), New York 1933.

Jonca, Karol, Spor Niemiecko Polski o Wzsiedlenie Zydow z Trzeciej Rzeszy (1938-1939), in: Acta Universitatis Wratislaviensis, Wroclaw 1990, S. 105-119.

Kaplan, Marion, Jüdisches Bürgertum: Frauen, Familien und Identität im Kaiserreich, Hamburg 1997.

Kershaw, Ian, The Persecution of the Jews and German Popular Opinion in the Third Reich, in: Leo Baeck Institute Yearbook 26 (1981), S. 261-289.

Ders., Popular Opinion and Political Dissent in the Third Reich: Bavaria 1933-145, Oxford 1983.

Kochavi, Arieh, Hanhalat ha-sochnut u-mezukat yehudci germania ve-austria me-haAnschluß ve-ad protz milchemet ha-olam ha-shnia, in: Dapim (Studies on the Holocaust Period) Bd. 3 (1984), S. 97-121 [The Zionist Executive and the Distress of the Jews in Germany and Austria, up to the Outbreak of World War II].

Kochavi, Jehojakim, Yahadut Germania - ha-shalav ha-acharon [Deutsche Juden - die letzte Phase], in: Shoat Yehudei Germania [Der Holocaust der deutschen Juden], 1998.

Korzec, Pawel, Antisemitism in Poland as an Intellectual, Social and Political Movement, in: Joshua A. Fishman (Hrsg.), Studies on Polish Jewry 1919-1939, New York 1974, S. 12-104.

Ders., Polen und der Minderheitenschutzvertrag (1919-1934), in: Zeitschrift für Ostforschung 24 (1975), S. 515-555.

Kramer, David, Jewish Welfare Work under the Impact of Pauperisation, in: Arnold Paucker (Hrsg.), Die Juden im Nationalsozialistischen Deutschland 1933-1943, Tübingen 1986, S. 171-188.

Kreutzberger, Max, Zionistische Vereinigung für Deutschland und soziale Volksarbeit, in: Bulletin des Leo Baeck Instituts, Nr. 51 (1975), S. 6-9.

Krikler, Bernard, Boycotting Nazi Germany, in: The Wiener Library Bulletin 23.4 (1969), S. 26-32.

Kübler, Thomas, Die Entwicklung der Sozialstruktur der jüdischen verfolgten Bevölkerung in Leipzig 1933-1939, Diplomarbeit Leipzig 1991.

Kulka, Otto Dov, ,Public Opinion' in National Socialist Germany and the Jewish Question' (hebr.), in: Zion 40 (1978), S. 186-290.

Ders., The ,Reichsvereinigung of the Jews in Germany (1938/39). Problems of continuity in the Organization and Leadership of German Jewry under the National Socialist Regime, in: Patterns of Jewish Leadership in Nazi Europe 1933-1945. Proceedings of the Third Yad Vashem International Historical Conference April 1977, Jerusalem, Yad-Vashem 1979, S. 45-58.

Ders. (Hrsg.), Deutsches Judentum unter dem Nationalsozialismus. Bd. 1: Dokumente zur Geschichte der Reichsvertretung der deutschen Juden, 1933-1939, Tübingen 1997.

Kwiet, Konrad, To leave or not to leave. German Jews at the Crossroads, in: Walter H. Pehle, November 1938, From „Kristallnacht“ to Genocide, New York 1990, S. 139-153.

Ders./Erschwege, Helmut, Selbstbehauptung und Widerstand. Deutsche Juden im Kampf um Existenz und Menschenwürde, Hamburg 1984.

Lambertie, Marjorie, Jewish Activism in Imperial Germany. The Struggle for Civil Equality, New Haven 1987.

Dies., The Centralverein and the Anti-Zionists - Setting the Historical Record Straight, in: Leo Baeck Institute Yearbook 33 (1988), S. 123-128.

Landau, Moshe, Miut yehudi lochem. Maavak yehudei Polin be-shanim 1918-1928, Jerusalem 1986 [The Jews as a National Minority in Poland, 1918-1928]. 
Ders., Ha-brit shehechsiva. Yehudim ve-Germanim be-congress ha-miutim ha-eiropi 1925-1933, Tel Aviv 1992 [The Disappointing Alliance. Jews and Germans in the European Minorities' Congress].

Laqueur, Walter, Toledot ha-Zionut, Tel-Aviv 1974 [History of Zionism].

Lavski, Hagit, Before Catastrophe. The Distinctive Path of German Zionism, Detroit 1996.

Lederhendler, Eli, Modernity without Emancipation or Assimilation? The Case of Russian Jewry, in: Jonathan Frankel/Steven Zipperstein (Hrsg.), Assimilation and Community. The Jews in Nineteenth-Century Europe, Cambridge 1992, S. 324-343.

Lestschinsky, Jacob, Ist Emigration eine Lösung? 10.6. 1936 (jidd.), in: ders., Erev Churban. Vom jüdischen Leben in Polen 1935-1937 (jidd.), Buenos Aires 1951.

Lotan, Giora, The Zentralwohlfahrtsstelle, in: Leo Baeck Institute Yearbook, Bd. VI, Jg. 1959, S. 185-208.

Mahler, Raphael, The Social and Political Aspects of the Haskalah in Galicia, in: Yivo Annula of Jewish Social Science 1 (1946), S. 64-85.

Margaliot, Abraham, Ha-t'guva ha-politit shel ha-mosadot ve-ha-irgunim ha-yehudim beGermania lenochach ha-mediniut ha-anti-yehudit shel ha-national sozialistim be-shanim 1932-1935, Diss., Jerusalem 1971 [The Political Reaction of German Jewish Organizations and Institutions to the anti-Jewish Policy of the Nationalsocialists, 1932-1935 (until the Publication of the Nuremberg Laws)].

Ders., The Problem of the Rescue of German Jewry during the Years 1933-1939. The Reasons for the Delay in their Emigration from the Third Reich, in: Rescue Attempts during the Holocaust. Proceedings of the Second Yad Vashem International Historical Conference, Jerusalem 1977, S. 247-265.

Ders., Hagirat yehudei germania: tichnun ve-meziut, in: Yahadut semaneinu (Contemporary Judaism) 5 (1989), S. 287-300 [The Emigration of German Jews: Plans and Reality].

Maurer, Trude, Ausländische Juden in Deutschland, 1933-1939, in: Arnold Paucker (Hrsg.), Die Juden im Nationalsozialistischen Deutschland, Tübingen 1986, S. 189-210.

Dies., Ostjuden in Deutschland 1918-1933, Hamburg 1986.

Dies., Abschiebung und Attentat. Die Ausweisung der polnischen Juden und der Vorwand für die ,Kristallnacht', in: Walter H. Pehle (Hrsg.), Der Judenpogrom 1938. Von der „Reichskristallnacht" zum Völkermord, Frankfurt a. M. 1988, S. 52-73.

Melzer, Emanuel, Ha-Diplomatia ha-polanit u-weayat ha-gira ha-yehudit be-shanim 1935-1939, in: Gal-Ed 1 (1973), S. 211-249 [Polish Diplomacy and Jewish Emigration during 1935-1939].

Ders., Relations between Poland and Germany and Their Impact on the Jewish Problem in Poland (1935-1938), in: Yad-Vashem-Studies 12 (1978), S. 193-230.

Ders., Ha-cherem ha-kalkali ha-yehudi ha-anti-germani be-Polin be-shanim 1933-1934, in: Gal-Ed 6 (1982), S. 149-166 [The Anti-German Economic Boycott by Polish Jewry in 1933-1934].

Ders., The Jewish and the German Minorities in Poland - Mutual Political Relations and Interactions, 1919-1939, in: Gal-Ed 13 (1993), S. 63-79.

Ders., Li-ve-ayat ha-gisanut ba-chevra ha-polanit be-shanim 1933-1939, in: Gal-Ed 14 (1995), S. 125-136 [On the Problem of Racism in Polish Society, 1933-139].

Ders., No Way out. The Politics of Polish Jewry 1935-1939, Cincinnati 1997.

Mendelsohn, Ezra, The Dilemma of Jewish Politics in Poland: Four Responses, in: Bela Vago/ George L. Mosse (Hrsg.), Jews and Non-Jews in Eastern Europe 1918-1945, New York 1974, S. 203-219.

Ders., Zionism in Poland. The Formative Years 1915-1926, New Haven 1981.

Ders., The Jews of East Central Europe Between the World Wars, Bloomington 1983.

Ders., German and Jewish Minorities in the European Successor States Between the World Wars. Some Comparative Remarks, in: ders./Chone Schmeruk (Hrsg.), Studies on Polish Jewry. Paul Glikson Memorial Volume, Jerusalem 1987, S. LI-LXIV.

Metz, K., Solidarität und Geschichte. Institution und sozialer Begriff der Solidarität in Westeuropa im 19. Jahrhundert, in: Kurt Bayertz, Solidarität: Begriff und Problem, Frankfurt a. M.1998, S. 172-194. 
Michman, Dan, Ze'ev Jabotinsky - Tochnit ,ha-Evakuazia' u-ve'ayat zfiat ha-Shoah, in: Kivunim 7 (1980), S. 119-125 [Ze'ev Jabotinsky - Der ,Evakuierungs'-Plan und das Problem der Erwartung der Shoah].

Milton, Sybil, Menschen zwischen Grenzen: Die Polenausweisung 1938, in: Menora 1 (1990), S. 184-206.

Dies., The Expulsion of Polish Jews from Germany, October 1938 to July 1939: A Documentation, in: Leo Baeck Institute Yearbook 29 (1984), S. 169-199.

Moses, Siegfried, Soziale Volksarbeit, in: Bulletin des Leo Baeck Instituts, Nr. 51, 14. Jg., 1975, S. $10-20$.

Mosse, George L., German Jews Beyond Judaism, Cincinnati 1985.

Mosse, Walter, From ,Schutzjuden“ to ,Deutsche Staatsbürger Jüdischen Glaubens': The Long and Bumpy Road of Jewish Emancipation in Germany, in: Pierre Birnbaum/Ira Katznelson, Paths of Emancipation. Jews, States and Citizenship, Princeton 1997, S. 59-93.

Munk, Michael L., Austrittsbewegung und Berliner Addas Jisroel Gemeinde 1869-1939, in: Herbert A. Strauss/Kurt R. Grossmann (Hrsg.), Gegenwart im Rückblick. Festgabe für die Jüdische Gemeinde zu Berlin 25 Jahre nach dem Neubeginn, Heidelberg 1970, S. 143 ff.

Ne'eman Arad, Gulie, Patriotismus als Agent von Akzeptanz. Sein Gebrauch und Mißbrauch durch die amerikanisch-jüdische Führung während der Nazi-Ära, in: Babylon 13-14 (1994), S. 12-38.

Niederland, Doron, Tfusei hagira shel yehudei Germania 1918-1938, Diss., Jerualem 1988 [German Jews Emigrants or Refugees? Emigration Patterns Between the Two World Wars].

Niewyk, Donald L., The Jews in Weimar Germany, Louisiana State University Press 1980.

Ders., The German Jews in Revolution and Revolt, 1918-1919, in: Studies in Comtemporary Jewry 4 (1988), S. 41-66.

Nicosia, Francis R., Jewish Affairs and German Foreign Policy During the Weimar Republic, Moritz Sobernheim and the Referat für jüdische Angelegenheiten, in: Leo Baeck Institute Yearbook 33 (1988), S. 261-283.

Oppenheimer, Israel, Tnuat he-halutz be-Polin, Beer Sheva 1993 [ The HeHalutz Movement in Poland 1929-1939].

Pascal, Eli, Mi-Danzig le-Lodz [From Danzig to Lodz], in: Shlomo Even-Shoshan (Hrsg.), Sipuro shel kibbutz Hachsara. Ha-kibbutz al shem ber borochov be-Lodz u-vnotea, Tel Aviv 1970, S. 91-94 [The Story of Kibbutz-Hakshara - Kibbutz Borocov at Lodz and its Surroundings].

Paucker, Arnold, Der jüdische Abwehrkampf gegen Antisemitismus und Nationalsozialismus in den letzten Jahren der Weimarer Republik, Hamburg 1968.

Ders., Die Abwehr des Antisemitismus in den Jahren 1893-1933, in: Herbert Strauss/Norbert Kampe (Hrsg.), Antisemitismus. Von der Judenfeindschaft zum Holocaust, Bonn 1985, S. 143-163.

Pinkus, Benjamin/Troen, Ian, Solidariut yehudit leumit baet ha-hadasha, Beer Sheva 1988 [National Jewish Solidarity in the Modern Period].

Polonsky, Antony, Politics in independent Poland 1921-1939. The Crisis of constitutional Government, Oxford 1972.

Prinz, Arthur, The Role of the Gestapo in Obstructing and Promoting Jewish Emigration, in: Yad-Vashem Studies II (1958), S. 205-218.

Pulzer, Peter, Gleichstellung und öffentliches Leben, in: Michael A. Meyer/Michael Brenner (Hrsg.), Deutsch-jüdische Geschichte in der Neuzeit, 3. Bd.: Umstrittene Integration 1871-1918, München 1997, S. 151-192.

Rabinowicz, Harry M., The Legacy of Polish Jewry. A History of Polish Jews in the Inter-War Years 1919-1939, New York 1965.

Rahden, Till van, Weder Milieu noch Konfession. Die situative Ethnizität der deutschen Juden im Kaiserreich in vergleichender Perspektive, in: Olaf Blaschke/Frank-Michael Kuhlemann (Hrsg.), Religion im Kaiserreich. Milieus - Mentalitäten - Krisen, Bd. 2: Religiöse Kulturen der Moderne, Gütersloh 1996, S. 409-434.

Ders., Situative Ethnizität versus Milieu-Identität. Die jüdische und die katholische Vergemeinschaftung im deutschen Kaiserreich in vergleichender Perspektive, in: H. Wassermann (Hrsg.), The History of Modern German Jewry (hebr.), im Druck. 
Reinharz, Jehuda, Fatherland or Promised Land. The Dilemma of the German Jew, 1893-1914, Ann Arbor, 1975.

Ders., Advocacy and History: The Case of the Centralverein and the Zionism, in: Leo Baeck Institute Yearbook 33 (1988), S. 113-122.

Reissner, H.G., The American Anti-Nazi Boycott, in: H. A. Strauss/H. G. Reissner (Hrsg.), Jubilee Volume dedicated to Curt C. Silberman, American Federation of Jews from Central Europe, New York 1969, S. 60-79.

Reitlinger, Gerald, Die Endlösung. Hitlers Versuch der Ausrottung der Juden Europas 1939-1945, Berlin 1979.

Rheins, Carl J., The Verband nationaldeutscher Juden, in: Leo Baeck Institute Yearbook 23 (1980), S. 243-268.

Rojanski, Rachel, Hashpaata shel yehadut arzot ha-brit al hakamat maarchot ha-revacha hayehudiot be-Polin be-shanim 1920-1929 [American Jewry's Influence upon the Establishment of the Jewish Welfare Apparatus in Poland, 1920-1929], in: Gal-Ed 11 (1989), S. 59-86.

Rowe, Leonard, Jewish Self-Defence: A Response to Violence, in: Joshua A. Fishman (Hrsg.), Studies on Polish Jewry 1919-1939. The Interplay of social, economic and political Factors in the Struggle of a Minority for its Existence, New York 1974, S. 105-149.

Rudnicki, Szymon, Ritual Slaughter as a Political Issue, in: Polin 7 (1992), S. 147-160.

Sagi, Nana/Lowe, Malcom, Research Report: Pre-War Reactions to Nazi anti-Jewish Policies in the Jewish Press, in: Yad Vashem Studies 13 (1980), S. 387-408.

Schiper, Yitzchak, Toldot ha-kalkala shel yehudei Polin ve-Lita mi-jamim rishonim ve-ad lechalukat ha-medina [Economic History of Polish and Lithuanian Jewry from their Origins until the Partition], in: Y. Heilprin (Hrsg.), Beit Yisrael be-Polin mi-yamim rishonim ve-ad li-ymot ha-churban, Bd. 1, Jerusalem 1948, S. 155-199 [Polish Jewry from its Origins to its Destruction].

Schramm, Gottfried, Die Ostjuden als soziales Problem des 19. Jahrhunderts, in: Heinz Maus (Hrsg.), Gesellschaft, Recht und Politik, Neuwied 1968, S. 353-380.

Ders., Die Juden im europäischen Osten um das Jahr 1900: Zwischenbilanz eines Minderheitenproblems, in: Gotthold Rhode (Hrsg.), Juden in Ostmitteleuropa von der Emanzipation bis zum Ersten Weltkrieg, Marburg 1989, S. 3-19.

Schüler-Springorum, Stefanie, Elend und Furcht im ,Dritten Reich'. Aus den Akten der Sammelvormundschaft der Jüdischen Gemeinde zu Berlin, in: Zeitschrift für Geschichtswissenschaft 7 (1997), S. 617-641.

Segev, Tom, The Seventh Million. The Israelis and the Holocaust, New York 1993.

Shamir, Haim, Beterem shoa. Redifat yehudei germania ve-daat ha-kahal be-ma'arav Europa, Tel Aviv 1974 [Before the Holocaust. Jews in the Third Reich and Western European Public Opinion 1933-1939].

Shavit, Yaacov, Me-rov li-medina. Ha-tnua ha-revisionistit ha-tochnit ha-hitiashvutit ve-haraaion ha-chevrati 1925-1935, Tel Aviv 1978, S. $71 \mathrm{ff}$. [From Majority to State, the Revisionist Movement: The Settlement Plan and the Social Cause 1925-1935].

Ders., Jabotinsky and the Revisionist Movement 1925-1948, London 1988.

Sorkin, David, The Impact of Emancipation on German Jewry: a Reconsideration, in: Jonathan Frankel/Steven Zipperstein (Hrsg.), Assimilation and Community. The Jews in NineteenthCentury Europe, Cambridge 1992, S. 177-198.

Steinert, Marlis G., Hitlers Krieg und die Deutschen. Stimmung und Haltung der deutschen Bevölkerung im Zweiten Weltkrieg, Düsseldorf 1970.

Stern, Eliahu, Minuio ve-ha-dachato shel ha-Rav Sagalovich ba-ir ha-chofshit Danzig (parasha ba-yechasim ben "ychudei ha-misrach" le-ven ha-yehudim ha-germanim), in: Gal-Ed 4-5 (1978), S. 345-363 [The Affair of Rabbi Sagalovich (Relations between German Jews and ,Ost-Juden' in the Interwar Period)].

Stern, Salma, The Court Jew. A Contribution to the History of the Period of Absolutism in Central Europe, Philadelphia 1950, S. 1-13.

Stillschweig, K., Die Juden Osteuropas in den Minderheitenverträgen, Berlin 1936.

Strauss, Herbert A., Jewish Emigration from Germany, Nazi Policies and Jewish Responses (I), in: Leo Baeck Institute Yearbook 25 (1980), S. 313-362.

Ders., Jewish Immigrants of the Nazi Period in the USA, New York 1987. 
Szaikowski, Zosa, The Struggle for Yiddish During World War I. The Attitude of German Jewry, in: Leo Baeck Institute Yearbook 9 (1964), S. 131-158.

Ders., Jewish Relief in Eastern Europe 1914-1917, in: Leo Back Institute Yearbook 10 (1965), S. 24-56.

Ders., East European Jewish Workers in Germany During World War I, in: Baron Salo Wittmayer - Jubilee Volume on the Occasion of his Eightieth Birthday, English Section, Vol. 2, Jerusalem/New York 1974, S. 887-918.

Ders., Western Jewish Aid, in: Joshua Fishman (Hrsg.), Studies on Polish Jewry 1919-1939, The Interplay of Social, Economic and Political Factors in the Struggle of a Minority for its Existence, New York 1974.

Teeni, Josef, Aliat Hitler la-shilton ve-hashpaata shel ha-antishemiut ha-polanit al mazavam shel yehudei polin ba-shanim 1933-1939, Diss., Jerusalem 1980 [Hitler's Rise to Power and the Influence of Polish Antisemitism on the Condition of Polish Jewry during the Years 1933-1939].

Thome, H., Soziologie und Solidarität: Theoretische Perspektiven für die empirische Forschung, in: Kurt Bayertz, Solidarität: Begriff und Problem, Frankfurt a. M. 1998, S. 217-262.

Thor, Malka, Amida ruchanit ve-hitmodedut hagutit shel Yehudei Germania im ha-mishtar ha-nazi, toch hadgashat teguvata shel ha-Yahadut ha-orthodoxit 1933-1939, unveröffentlichte M.A.-Arbeit, Jerusalem 1989 [Die intellektuelle Bewältigung des NS-Regimes durch die deutschen Juden, unter besonderer Berücksichtigung der Reaktionen des orthodoxen Judentums, 1933-1939].

Tomaszewski, Jerzy, Vladimir Jabotinsky's Talks with Representatives of the Polish Government, in: Polin 3 (1988), S. 276-293.

Ders., Michtavim mi-Zbanszyn [Briefe aus Zbanszyn], in: Yad-Vashem Kovetz Mechkarim 19 (1989), S. 227-149.

Ders., Polish Diplomats and the Fate of Polish Jews in Nazi Germany, in: Acta Poloniae Historica 61 (1990), S. 115-127.

Ders., The Civil Rights of Jews in Poland 1918-1939, in: Polin 8 (1994), S. 115-127.

Toury, Jacob, Die politischen Orientierungen der Juden in Deutschland. Von Jena bis Weimar, Tübingen 1966.

Ders., Die Sprache als Problem der jüdischen Einordnung im deutschen Kulturraum, in: Walter Grab (Hrsg.), Gegenseitige Einflüsse deutscher und jüdischer Kultur von der Epoche der Aufklärung bis zur Weimarer Republik (Jahrbuch des Instituts für Deutsche Geschichte), Tel Aviv 1982, S. 75-96.

Ders., Der Prozeß der Lokal-Emanzipation - Herausbildung jüdischer Bürgerrechte in deutschen Ortschaften, in: ders., Deutschlands Stiefkinder. Ausgewählte Aufsätze zur deutschen und deutsch-jüdischen Geschichte, Gerlingen 1997, S. 127-158.

Troen, Ian, Organizing Rescue: National Jewish Solidarity in the Modern Period, London 1992.

Tydor-Baumel, Judith, La-Berur ha-histori shel shtei sugiot halachtiot she-nitoreru bi-tekufat ha-shoah, in: Sinai 46 (1982), S. 156-167 [Zur historischen Klärung zweier halachischer Fragen aus der Zeit der Shoah].

Volkov, Shulamit, Antisemitism as a Cultural Code, in: Leo Baeck Institute Yearbook 23 (1978), S. 25-46.

Dies., Die Verbürgerlichung der Juden in Deutschland als Paradigma, in: Jürgen Kocka (Hrsg.), Bürgertum im 19. Jahrhundert. Deutschland im europäischen Vergleich, Bd. 2, München 1988, S. 343-371.

Dies., Die Jüdische Gemeinde in Altona, 1867-1890. Ein demographischer Überblick, in: Peter Freimark/Arno Herzig (Hrsg.), Die Hamburger Juden in der Emanzipationsphase (1780-1870), Bd. 2, Hamburg 1989, S. 343-371.

Dies., Die Dynamik der Dissimilation: Deutsche Juden und die ostjüdischen Einwanderer, in: dies., Jüdisches Leben und Antisemitismus im 19. und 20. Jahrhundert, München 1990, S. 166-180.

Dies., Jews among the Nations: A Unique National Narrative or a Chapter in National Historiographies, in: Zion 61.1 (1996), S. 91-111. 
Vollnhals, Clemens, Jüdische Selbsthilfe bis 1938, in: Wolfgang Benz (Hrsg.), Die Juden in Deutschland 1933-1945. Leben unter nationalsozialistischer Herrschaft, München 1989, S. 314-411.

Walk, Joseph, Jüdische Schule und Erziehung im Dritten Reich, Frankfurt a. M. 1991.

Weinryb, Dov, Teudot le-toldot ha-yehudim be-Polin [Documents on Jewish History in Poland], in: ders., Mechkarim u-mekorot le-toldot Israel baet ha-chadasha, Jerusalem 1976, S. 121-165 [Studies and Sources on Jewish History in the Modern Era].

Ders., Yehudei Polin mechutz le-Polin [Polnische Juden außerhalb Polens], in: Y. Heilprin (Hrsg.), Beit Yisrael be-Polin mi-yamim rishonim ve-ad li-ymot ha-churban), Bd. 2, Jerusalem 1948, S. 218-227 [Polish Jewry from its Origins to its Destruction].

Weiss, Yfaat, Schicksalsgemeinschaft im Wandel. Jüdische Erziehung im nationalsozialistischen Deutschland 1933-1938, Hamburg 1991.

Dies., ,Ostjuden' in Deutschland als Freiwild. Die nationalsozialistische Außenpolitik zwischen Ideologie und Wirklichkeit, in: Tel Aviver Jahrbuch für deutsche Geschichte 23 (1994), S. 215-232.

Dies., Projektionen von, Weltmacht' - Die Boykottbewegung der 1930er Jahre, in: Tel Aviver Jahrbuch für Deutsche Geschichte 26 (1997), S. 151-179.

Dies., Wir Westjuden haben jüdisches Stammesbewußtsein, die Ostjuden haben jüdisches Volksbewußtsein'. Der deutsch-jüdische Blick auf das polnische Judentum in den beiden ersten Jahrzehnten des 20. Jahrhunderts, in: Archiv für Sozialgeschichte 37 (1997), S. 157-178.

Dies., Homeland as Shelter or as Refuge? Repatriation in the Jewish Context, in: Tel Aviver Jahrbuch für deutsche Geschichte 27 (1998), S. 195-220.

Dies., Emigration Efforts of ,Repatriation'. The Issue of the Relationship between Jewis-Polish Emigrants and the Jewish-German Establishment, in: David Bankier (Hrsg.), Probing the Depths of German Antisemitism: German Society and the Persecution of the Jews, 1933-1941, New York 1999, S. 360-370.

Wertheimer, Jack, Unwelcome Strangers, East European Jews in Imperial Germany, New York 1987.

Wildt, A., Solidarität - Begriffsgeschichte und Definition heute, in: Kurt Bayertz, Solidarität: Begriff und Problem, Frankfurt a. M. 1998, S. 202-261.

Wildt, Michael, Gewalt gegen Juden in Deutschland 1933-1939, in: WerkstattGeschichte 18 (1997), S. 59-80.

Wislicki, A., The Jewish Boycott Campaign against Nazi Germany and its Culmination in the Halbersztadt Trial, in: Polin 8 (1994), S. 282-289.

Wollstein, Günter, Das „Großdeutschland“ der Paulskirche. Nationale Ziele der bürgerlichen Revolution 1848/49, Düsseldorf 1977, S. 98-188.

Yahil, Leni, Madagascar - Phantom of a Solution for the Jewish Question, in: George Mosse/ Bela Vago (Hrsg.), Jews and Non-Jews in Eastern Europe 1918-1945, New York/Toronto/ Jerusalem 1974, S. 315-334.

Dies., The Holocaust: The Fate of European Jewry, New York 1990.

Yisraeli, David, Ha-Reich ha-germani ve-Erez Israel. Beayot Erez Israel ba-mediniut ha-germanit ba-shanim 1889-1945, Ramat Gan 1974 [The German Reich and Palestine: The Problems of Palestine in German Policy 1889-1945].

Zariz, Rut, Bricha be-terem shoa. Hagira mi-Germania be shanim 1938-1941, Tel Aviv 1990 [Escape before the Holocaust. Migration of German Jews 1938-1941].

Zechlin, Egmont, Die deutsche Politik und die Juden im Ersten Weltkrieg, Göttingen 1969.

Zipperstein, Steven, Haskalah, Cultural Change and Nineteenth-Century Russian Jewry: A Reassessment, in: Journal for Jewish Studies 35. 2 (1983), S. 191-207. 


\title{
Abkürzungsverzeichnis
}

\author{
AAN \\ Archiwum Aktow Nowych \\ BAK \\ Bundesarchiv Koblenz \\ BAP \\ Bundesarchiv Potsdam \\ BLHA \\ Brandenburgisches Landeshauptarchiv
}

CAHJP Central Archives for the History of the Jewish People

C.V.Z.

Centralvereins Zeitung

CZA

Central Zionist Archives

GFH

Beit Lochamei-HaGhettaot (Ghetto-Fighter-House)

GStA Merseburg Staatsarchiv Abteilung Merseburg

JDC

JfCJ

Jewish Joint Distribution Committee

Centre for Oral Documentation at the Institute for Contempo-

JR rary Jewry

(K.f.d.O. Komitee für den Osten)

$\mathrm{LaB}$

Landesarchiv Berlin

LBIJ

Leo Baeck Institute Jerusalem

LBI-N.Y.

Leo Baeck Institute Archiv, New York

LI

Archiv der Arbeiterbewegung im Lavon-Institut

ORT

Obščestvo Rasprostranenija Truda sredi Evreev (Gesellschaft zur Förderung der körperlichen Arbeit unter den Juden)

OSE

Obščestvo Zdravochranenija Evreev (Gesellschaft für Gesundheitsschutz der Juden)

PAAA Politisches Archiv des Auswärtigen Amtes

RKI Rav-Kook-Institute

RV

Rekonstruiertes Archiv der „Reichsvertretung der deutschen Juden"

SoA

Sonderarchiv

StA Dresden Sächsisches Hauptstaatsarchiv Dresden

StA Hamburg

StA Leipzig

Staatsarchiv Hamburg

Staatsarchiv Leipzig

TOZ

Towarzystwo Ochrony Zdrowia Ludnosci Zydowskiej (Gesellschaft für Gesundheitsschutz der Juden) 
YIVO

YVA

ZIH
YIVO Institute for Jewish Research Archive Yad-Vashem-Archiv

Zydowski Instytut Historyczny 


\section{Glossar}

Adass Jershurun (Gemeinde Jershuruns): Orthodoxe Austrittsgemeinden aus den zur Reform tendierenden Einheitsgemeinden im Deutschland des 19. Jahrhunderts (in einigen Städten, so z. B. Berlin, auch als Adass Jisroel bezeichnet).

Agudat Israel: 1912 in Kattowitz gegründete orthodoxe politische Partei, die die Halacha als Basis jüdischen Lebens bewahren will. Ursprünglich entstanden als Gegenbewegung zu den säkularen politischen Bewegungen Osteuropas, wie Bund, Zionismus sowie dem Reformjudentum.

Aliya : Einwanderung nach Israel; Bezeichnung für die verschiedenen Einwanderungswellen nach Palästina/Israel seit 1880.

Ashkenaz: Bezeichnung für das erste relativ kompakte jüdische Siedlungsgebiet in Nordwesteuropa, das am Rhein gelegen war. Ausgehend davon wurde der Begriff auf deutsche Juden und ihre Nachkommen in anderen Staaten, vor allem in Osteuropa angewandt.

Bachad (Brit Chalizim Datiim: Bund religiöser Pioniere): Eine von Deutschland ausgehende national-religiöse Bewegung junger Pioniere, die versuchten, streng religiöse Ideen mit anderen Strömungen - vor allem dem Sozialismus - zu verbinden. Der Bachad gründete in den 1930er Jahren orthodoxe Kibbutzgemeinschaften.

Brit ha-birionim: Aufsehenerregende, wenngleich politisch einflußlose Aktivistengruppe mit faschistoiden Zügen unter der Leitung Aba Achimeirs. Dem Brit ha-birionim kommt insofern eine weiterreichende Bedeutung zu, als er in Ansätzen als Inspirationsquelle für den Irgun und die Stern-Gruppe, zwei rechtsgerichtete Untergrundorganisationen, diente.

Chaluz: Pionier in Eretz Israel; wurde hauptsächlich auf in der Landwirtschaft tätige Pioniere angewandt.

Ha'awarah Gesellschaft (ha'awarah = hebr. Transfer): Treuhandgesellschaften in Palästina und Deutschland, die die Abwicklung des 1933 zwischen der Jewish Agency und dem Reichswirtschaftsministerium geschlossenen Transferabkommens durchführten. Im Rahmen des Transferabkommens wurde Kapital jüdischer Emigranten, das bei der deutschen Treuhandgesellschaft deponiert wurde, mit Warenexporten des nationalsozialistischen Deutschland nach Palästina verrechnet.

Hachschara (Ausbildung): Vorbereitung und berufliche Ausbildung für Pioniere auf ein Arbeiterleben in Palästina. In Deutschland umfaßte die Hachschara-Arbeit nach den Richtlinien der Hechaluz-Konferenz von 1922 u.a. die Einrichtung einer zentralen Stellenvermittlung, die fachliche Förderung von Chaluzim, das Angebot von Hebräischkursen etc. 
Halacha: Ein einzelnes, anerkannten Gesetz der rabbinischen Gesetzgebung; allgemeine Bezeichnung für des Rechtssystem des Judentums.

Ha-Poel Ha-Zair (Der Junge Arbeiter; Kurzform für: Histradut ha-Poalim haZirim): 1905 gegründete jüdische Arbeiterpartei (bis 1930). Ursprünglich Interessenvertretung der Einwanderer der zweiten Aliya. Ziel von Ha-Poel Ha-Zair war die Verstärkung des jüdischen Anteils in allen Arbeitsfeldern in Eretz Israel. Ideologische Differenzen im Bezug auf Jiddisch und sozialistische Ideen bestanden zur Poalei Zion.

He-Chalutz (der Pionier): In Folge der Pogromwellen der 1880er Jahre in Osteuropa entstandene Vereinigung jüdischer Jugendlicher, die ihre Mitglieder für landwirtschaftliche Tätigkeiten in Eretz Israel ausbildete.

Hetter: Eine dem jüdischen Religionsgesetz entsprechende Erlaubnis (Issur vehetzter bezeichnet den Kanon dessen, was nach dem jüdischen Gesetz verboten und gestattet ist).

Jereim: Strengorthodoxe Juden

Jeschuw (Ansiedlung): Bezeichnung für die jüdische Bevölkerung Palästinas. In der Regel wird zwischen altem und neuem Jeschuw unterschieden. Der alte Jeschuw bezeichnet dabei Siedlungen vor allem an heiligen Stätten, die vor der zionistischen Einwanderung und auch später aus religiösen Motiven in Palästina entstanden. Der neue Jeschuw entstand in Folge der von zionistischen Ideen geprägten Einwanderung seit 1882, verstärkt dann nach dem Ersten Weltkrieg (in deutschsprachigen Nachschlagewerken auch als Jischuw bezeichnet).

Kaschrut: Einhaltung der jüdischen Speisegesetze.

Misrachi: 1902 gegründete religiös-zionistische Partei.

Mitzwa: Biblische oder rabbinische Anordnung; auch: gute oder wohltätige Tat.

Pejes: Schläfenlocken religiöser Juden.

Pessach (Überschreitungsfest): Acht (nach der Bibel eigentlich nur sieben) Tage andauerndes Fest, das an den Auszug Israels aus Ägypten erinnert. In der Antike war Pessach zugleich eines von drei Erntefesten. Dem ,Pessach aus Ägypten wurde in späterer Zeit das ,Pessach der Zukunft beigefügt, um die Hoffnung auf eine Beendung der Diaspora-Situation und den Beginn der messianischen Zeit zu beschreiben.

Poalei Zion: Sozialistische Arbeiterpartei, die Zionismus und Sozialismus zu verbinden bemüht war. Vorläufer und einzelne Gruppierungen existierten seit den 1890er Jahren, 1907 wurde die World Union ins Leben gerufen, die 1920 jedoch wieder zerbrach.

Schechita: Rituelles Schlachten von nach den jüdischen Speisegesetzen zum Verzehr gestatteten Tieren durch Durchtrennen der Halsschlagader. 


\section{Personenregister}

Adelson, Jozef 21

Adler, Cyrus 27, 96

Adler-Rudel, Shalom 100

Aharonowicz, Zalman (Aran) 182

Aharonowitz, Joseph $187 \mathrm{ff}$.

Alter, Viktor 98

Arlosoroff, Chaim 152, 184, 188

Arlt, Fritz 50

Artiscewski, Tomas 210

Awerbuch 213

Baeck, Leo 37, 221

Baerwald, Paul 89, 92

Beck, Jozef 109, 111, 137, 158, 207

Beilinson, Moshe 175, 187, 190

Ben-Chorin, A. 181

Ben-Gurion, David 125, 153, 162f., 177, 184

Bentwich, Norman 161

Berger, Fritz 214

Blumenfeld, Kurt 174f., 221

Breuer, Raphael 49

Brodnitz, Friedrich $95 \mathrm{f}$.

Cohn, Conrad 214

Deutsch, Norbert 40

Dmowski, Roman 107, 133

Dobkin, Elijahu 157, 163

Eichmann, Adolf 132

Einstein, Albert 35

Eppstein, Paul 213-216

Erlich, Henryk 210

Eschelbacher, Max 203

Feuchtwanger, Lion 17

Freier, Recha 212-216

Frick, Wilhelm 31

Frumkin, Heschel 154

Giterman, Isaac 204, 208

Goldmann, Nahum 75, 85f., 158, 161, 177, $183,188 \mathrm{f}$.

Golomb, Elijahu 182, 191

Gottlieb, Yehoshua 114, 120, 166

Grünbaum, Yitzchak 74f., 136, 152-155, 157 f., 177 f., 187, 189, 191, 193f., 222
Grudzanski, Chajim Ozer 60, 62, 64, 68

Grynszpan, Herschel 197

Herzl, Theodor 178

Hildesheimer, Esriel $173 \mathrm{f}$.

Himmler, Heinrich 196

Hindenburg, Paul von 37

Hirsch, Otto $216 \mathrm{f}$.

Hirsch, Samson Raphael 70

Hitler, Adolf 29, 36, 48, 106, $117 \mathrm{ff}$., $123 \mathrm{f}$., $131,133,165,167,177,187,189 \mathrm{ff} ., 196$, 221, 224

Hoffmann, Ben-Zion 181

Holländer, Ludwig 35

Horovitz, Jakob 63

Hos, Dov 186

Hyman, Josef 92f, 96, 143, 164, 211

Jabotinsky, Wladimir Ze'ev 122, 136f., 178, 184

Josephtal, Georg 156

Kahn, Bernard 27, $91 \mathrm{ff} ., 96 \mathrm{ff} ., 125,144$, $210 \mathrm{f}$.

Kaplan, Eliezer $\quad$ 154, 182, 184, 188

Kareski, Georg 137

Katznelson, Berl 162

Klee, Alfred $55 \mathrm{f}$.

Kleinbaum, Moshe 76, $110 f ., 121,128,221$, $229 \mathrm{f}$.

Komarnicki, Tytus 164

Koscialkowski, Marian Zyndram 210

Kreutzberger, Max 90, 92, 99

Landauer, Georg 154, $156 f ., 163$

Laski, Neville 95

Leon, Franz 215

Lestschinsky, Jakob 124, 135

Levin, Aron 123

Levit, Leon 166

Lipski, Jozef 165, 195f., 207

Margulies, Emil 85f., 178, 222

Mark 56

Marminski, Israel 154, 187

Mautner, Otto $38 \mathrm{f}$.

Mayer, Franz 156, 158 
Mazur, Elijahu 175

Melchett, Lord Alfred Monde 123

Merzbach, Jakob 63

Meyerson, Golda (Meir) $189 \mathrm{f}$.

Mincberg, Leib 68, 114, 126

Moltke, Hans Adolf von 111

Munk, Esra $63 \mathrm{f}$.

Nathan, Paul 139

Naumann, Max 36ff. (36-41 NaumannGruppe)

Neurath, Konstantin Freiherr von 31

Oppenheimer, Franz $219 \mathrm{f}$.

Ortner, Moshe $212 \mathrm{f}$.

Pilsudski, Jozef $15,65,93,106,108,118,123$

Plaut, Max 203

Poniatowski, Juliusz 67

Potocki, Jerzy 164

Prinz, Artur 216

Prystor, Janina $66 \mathrm{ff}$.

Rabin, Israel 55

Raczkiewich, Vladislaw 126

Rasner, Chaim 175f., 182

Rau, Arthur 156

Remez, David 189

Ringelblum, Emmanuel 207, 209

Ribbentrop, Joachim von 165, 196

Roosevelt, Franklin D. 159, 164

Rosenberg, Alfred 105

Rosenberg, James 92

Rosmarin, Henryk 166, 182

Rozen, Josef 60

Rothschild, Baron Robert de 121

Rubashov (Shazar), Zalman 173, 179, 186

Rubinstein, Isaak 68, 114, $222 \mathrm{f}$.

Rublee, George $166 \mathrm{f}$.

Ruppin, Arthur 153f., 157, 161, 163, 178
Sagalovich, Jacob 53

Samuel, Herbert 155

Schacht, Hjalmar 167

Schmorek, Emil 181

Schorr, Moshe 68, 72, 114, 134, 206

Schweitzer, David 99, $143 \mathrm{f}$.

Senator, Werner 153-157, 161, 190

Shertok, Moshe (Sharett) 184, $188 \mathrm{f}$.

Singer, Israel Joshua 17

Skladkowski, Slawoj 115

Sneh, Moshe siehe: Kleinbaum, Moshe

Sokolow, Nachum 85

Sommerstein, Emil 68, 114

Sprinzak, Josef 188

Stahl, Heinrich 213

Staveski, Abraham 184

Syngalowski, Aaron 86

Tenenbaum, Joseph 181

Treitschke, Heinrich von 24

Trockenheim, Jacub 68, 72f., 114

Troper, Morris 211

Trzeciak, Stanislaw 65

Tygel, Zelig 96, 180

Unna, Isak 54,63f.

Ussischkin, Menachem 162

Volkowicz 182

Waldman, Maurice 164

Warburg, Max 54f., 95 f., 138

Weinberg, Jehiel Jacob 60,62

Weizmann, Chaim 74f., 102, 158, 192

Weltsch, Robert 128, 221

Wise, Jona B. $88 \mathrm{f}$.

Wise, Stephen 75,180

Wolf, Heinrich 169

Zimel, Max 214

Zirelson, Jehuda 60 